\title{
AN ANALYSIS OF WAR LANGUAGE IN COVID 19 SPEECHES: A COMPARATIVE STUDY

\author{
Kanwal Gulzar ${ }^{1}$, Saira Asghar Khan², Imdad Ullah Khan ${ }^{3 *}$, Saood Khan ${ }^{4}$, Sidra Amina ${ }^{5}$ \\ ${ }^{1,2}$ Fatima Jinnah Women University, Pakistan; ${ }^{3 * 4}$ University of Swat, Pakistan; ${ }^{5}$ University of Lahore, Pakistan. \\ Email: ${ }^{1}$ sauoodkhan896@gmail.com, ${ }^{2}$ sairakhan@fjwu.edu.pk, ${ }^{3}$ imdad.Khan@ uswat.edu.pk, \\ ${ }^{4}$ kanwalgulzar799@yahoo.com, 5 sidraamina786@gmail.com
}

Article History: Received on $16^{\text {th }}$ June 2021, Revised on $27^{\text {th }}$ June 2021, Published on $29^{\text {th }}$ June 2021

\begin{abstract}
Purpose of the study: The study aims to include the hidden ideology working behind the metaphor that is used in the speeches of both countries. It will also analyze the source domains used by both countries and will explore whether the two countries are employing similar source domains or using different source domains.
\end{abstract}

Methodology: The Theoretical framework of Critical Metaphor Analysis (CMA) by Charteris-Black (2004) has been employed to study the metaphors used.

Main Findings: The results reveal that the USA is quite racist in its president naming the virus CHINESE VIRUS, and it appears as an authoritative, dominant, and strong nation that intends to hold its supremacy all around the world. Whereas the UK shows its nationalistic approach. The source domains of War, Enemy, soldier, Home front are found to be a similar while different source domains used are wartime president, victory in the USA, and Blitz spirit, wartime government in the UK.

Applications of this study: As the ideologies of the different governments have been linguistically assessed through the metaphorical frameworks used, this study is a helpful study to understand the stance being used by the different governments in dealing with universal problems. It can be helpful in political studies of governmental responses.

Keywords: Ideology, Entailments, War Metaphors, Critical Metaphor Theory, COVID 19 Speeches.

\section{INTRODUCTION}

The novel coronavirus begins from the city of China, Wuhan, and has spread around the whole world. It has fast become a threat to human health and well-being. It is historically proved that when nations experience "Unprecedented Times", it gives rise to new vocabulary which is added into the World's dictionary. As coronavirus is spreading all around the globe, new words, analogies, acronyms are being created, which are transferring to us through different media sources. The countries are using different analogies to relate the situation of COVID-19. Using metaphorical language for this situation reflects the ideologies lying behind the conversation and also of the speaker. The use of metaphor in the language tells about the cognitive and pragmatic thought processes which lead to shape the understanding of public opinions. The metaphorical language helps the public psychologically to decide on how to respond to the complex events going around them.

Metaphors provide a useful tool for linguists to analyze ideologies implicit within language. (CMT; Lakoff, 1993; Lakoff and Johnson, 1980, Wise,2020). As metaphors have the persuasive power to define reality through a coherent network of entailments that highlight some features of reality and hide others. This leads to emerging ideologies embedded in the metaphoric language in any discourse.

With the rise of this novel pandemic, the western countries particularly, the USA, UK, have used WAR metaphors in their rhetorical speeches, specifically the one that helps to navigate to unfamiliar territory by transferring ideas about the known to the unknown. By using metaphoric language in speeches, certain cognitive and communicative realities have been exposed(Flusberg, S. J., Matlock, T., \& Thibodeau, P. H, 2018). Similarly, conceptual metaphors contain systematic mappings i.e Source domain and target domain, that helps in explaining the linguistic realization of all conceptual metaphors (Semino, 2021).

The present study aims to analyze the hidden ideologies in warfare language used in public and press rhetorical speeches by the USA and UK. It will also examine whether the two countries are using similar source domains of WAR or employing different source domains in the speeches. As all previous research has shown that various medical and political issues addressed in public discourse are examined in terms of wars (Flusberg, S. J., Matlock, T., \& Thibodeau, P. H, 2018). With the help of Critical Metaphor Analysis by Charteris-Black (2004), this study will discuss how these war metaphors might impact the people who are addressed.

Following questions are being addressed in this study,

1. How are ideologies encoded through war metaphors in the speeches of two selected countries?

2. Do the governmental speeches employing similar source domains or different domains? 


\section{REVIEW OF LITERATURE}

The use of language to influence global communication has been emphasised in many studies (Lowe, 2018 Smith, Johnston-Robledo, McHugh \& Chrysler, 2010), which has shown how specific language use can put a powerful impact on individual's mindset as well as their perceptions. According to Aristotle's writing (1404-1505), metaphors have been viewed to represent unfamiliar as familiar and by comparing an unknown thing to a known thing. The term 'Metaphor' has Greek roots" meta" means carrying over, "'phoros " means' 'light ", implies that the speaker illuminates the unfamiliar things into the attention of the auditor and ties the familiar, to the unfamiliar one. Although metaphors have been treated as literary devices used as figurative language and in literary criticism. Metaphors also operate to shape cognition and actions. This may lead to developing structural metaphors. According to Lakoff (2004), metaphors are strong frames that guide more than one language. They shape the goals we seek, the plans we make, the way we act, and what counts as a good or bad outcome of our actions" so from here we can say that how metaphors become structure about the way we think about the topic, to make some plans, goals, actions, and outcomes rhetorical and others nonrhetorical. Auditors seek to enact certain plans, policies, actions that are entailed from that particular metaphor and judge whether that metaphor has any accurate description of reality (Ivie, 1984; Bates, 2004; Bates,2020).

When the metaphor of WAR is transferred to help auditors understand other contexts, in their making the familiar unfamiliar the entailments of these metaphors can lead to affirming other understandings of associated persons, events, or phenomena, whether these affirmations are intentional or unintentional. For example, Mirghani (2011) examined anticopyright infringement campaigns' declaration of a WAR on PIRACY. She concludes that, by transforming computer users into PIRATES, the term's "historical baggage and its power as a provocative latent discourse" allow copyright enforcers to place PIRATES outside the law and its protections, and to authorize themselves "as a disciplining and policing force by evoking military metaphors" (p. 115). The entailments are deployed to describe the ideologies behind structuring the metaphor. Ideology is a belief system or a social cognition shared in/by a group. (Van Dijk, 1998,2000, 2001). Van Dijk further suggests 'the basis of the social representations shared by members of a group' (Van Dijk, 1998:8), ideology is constituted by 'basic propositions that represent what is good or bad for the group' (Van Dijk, 2000: 95).

Linguists have conducted many pieces of research on conceptual metaphor theory (CMT; Lakoff, 1993; Lakoff and Johnson, 1980), a recent emergent field that provides a useful tool to analyze ideologies that are implicit within language. Metaphors are taken as linguistic devices and are deeply rooted in language, thought and action, pervading everyday life. Lakoff and Johnson (1980: 157) proposed that metaphors have the persuasive power 'to define reality [. . .] through a coherent network of entailments that expose some features of reality while hiding others.

Few scholars investigate conceptual metaphors to expose ideologies behind them (Charteris-Black, 2004; Koller, 2005; Semino, 2002; Semino and Mašci, 1996; White and Herrera, 2003; Guo 2013). Charteris-Black (2004, 2005) attempted to improve Lakoff and Johnson's conceptual metaphor theory by paying close attention to the semantic and pragmatic aspects of metaphor occurring in daily communication, instead of merely focusing on the cognitive aspects. CharterisBlack(2004) and other scholars started to integrate CDA with CMT, creating a new perspective of metaphor analysis called Critical Metaphor Analysis (CMA), which explores the context of metaphor and the implicit speaker intention as well as the covert power relations within the social and cultural context. This study has adopted the method of CharterisBlack's (2004) Critical metaphor analysis (CMA). According to CMT, metaphors involve two conceptual domains: (1) the 'source' domain consisting of attributes or entities such as 'animals', 'buildings and construction', 'the human body, etc., that are linked in the mind and expressed through lexical choices, and (2) the 'target' domain which tends to be abstract and includes 'emotion', 'life and death, 'time', etc., and is basically what we are trying to understand (Lakoff \& Johnson, 1980).

According to CMA, a speaker's ideological perspective can be expressed in different ways, i.e. a similar notion can be represented through different metaphors and the same metaphor may also be used in different ways (Charteris-Black, 2004). For example, in a developed country, the metaphor 'Society is a market' might be used to refer to the sense of competitiveness of a particular society, while in a developing country, society is taken as an entity emphasizing the value of cooperation, where everyone depends on others to survive. (Machin \& Mayr, 2012, p. 166). Critical Metaphor analysis involves three stages to analyze the data.

\section{A. Metaphor identification}

In this stage, the metaphors are figured out from the text to see if they are metaphors giving metaphoric meanings or just literal meanings to auditors.

Excerpts from the actual text will be presented in this section to share details with the readers.

\section{B. Metaphor Interpretation}

This stage is very important. In this section. The text is unveiled to bring out the hidden ideologies and meanings to convey to readers. In other words, this section shows the relationship between the reader and the producer of the text.

\section{Metaphor Explanation}


This section explains the use of metaphors, its goal of persuading, and tells the actions and thoughts about the hidden ideas. It helps in identifying the discursive functions of metaphors.

There are studies conducted on metaphorical language in different domains. There is one performed by $\underline{\text { Chiang and }}$ Duann in 2007, on Conceptual Metaphors on Severe acute respiratory syndrome(SARS) The researchers contend to examine how political agendas and underlying ideologies of newspapers pervade their use of metaphors. Three newspapers (Liberty Times, The United Daily News, and The People's Daily) have been chosen to study the conceptual metaphors on Severe acute respiratory syndrome (SARS). The findings show that the metaphors, THE DISEASE IS WAR is employed to construct Self and Other representation while other metaphors are DISEASE IS DISASTER. This study concludes with a remark that these metaphors are used in the political domain rather than as a medical discourse.

Similarly, Panzeri. F et al (2021) has examined in their study that presenting COVID 19 pandemic as a War affects people's reasoning about it or not. The idea behind conducting this research is to analyse how conceptual metaphors influence the audience's behaviours towards the disease. So, the findings suggest that metaphorical framing effects do not occur by default. It is also said that the metaphor framing effect is not manifest in all individuals, rather it is manipulated by, and subordinated to, psycho-social variables such as participants' political preferences and reading habits.

In another study conducted by Sudajit (2017) she examines how the Home for Children with Disabilities and disability identities were construed by Thai undergraduates in their website project. They analyze the use of metaphors and the participants' enactment of identity and social representation with the help of Critical Metaphor Analysis (CMA). The researcher analyzes metaphors of JOURNEY, FAMILY, OBJECT, HOME in the data and that these all are utilized to reproduce the Home for Children with Disabilities identity as a 'warm', 'effective', and 'altruistic' organization that provides their children with forms of care and compassion. Moreover, the findings of participant's interviews suggest that participants' representation of disability identity as a non-static and changeable entity.

The current study is carried out on the use of WAR metaphors by two western countries to study how these metaphors address different entailments in the speakers' talk. This comparative study aims to encode ideologies hidden in the speeches of COVID 19, by using the CMA approach, of two countries namely the United Kingdom (UK) and the United States of America (USA). It will also analyze whether the two countries employ similar source domains for war metaphors in their speeches or have used them differently. So this study will check how ideologies are encoded through war metaphors in the speeches of the selected countries and do these speeches employ similar source domains of WAR or use different domains.

\section{METHODOLOGY}

This is a descriptive qualitative study that attempts to explore a comparison of how countries like the United Kingdom and the United States have employed different war metaphors to address the phenomenon of Coronavirus. This leads to bringing out ideologies working behind metaphorical language in their speeches. All speeches delivered during public meetings, press conferences by US president, Donald Trump have been collected to extract the war metaphors. Similarly, speeches executed by UK Prime minister, Boris Johnson, and Queen Elizabeth have been recorded for analysis. Eight speeches have been selected from websites of USA and nine speeches are selected from UK Websites for analysis. This research has also taken the Queen's message because, during March, Boris Johnson was hit by Coronovirus and he was unable to deliver any public speech. During that time Queen Elizabeth address Britons to show solidarity in this situation. The time span of data collection is from 1st March 2020 till 10th April 2020. The sample is collected purposively. The Critical Metaphor Analysis (CMA) proposed by Charteris- Black (2004) has been adopted for the analysis of COVID19 speeches.

\section{DATA ANALYSIS}

\section{Critical Analysis of Metaphors}

The speeches related to coronavirus are analyzed to see how metaphors are employed by the speakers to reproduce a mental representation of the phenomena and also to analyze what lay between the speaker's thoughts or cognitive processes and statements they made about the Global pandemic coronavirus. The process of Metaphorical construction analysis suggested by Charteris-Black (2004) has been adopted to study the objectives of the present research. The initial stage of choosing the metaphor started with identifying the use of metaphors in each segmented instance and labeling the concept behind each use of metaphor. The context of the speeches and statements are critically examined again and again to see whether the identified words are metaphors and not literal words. A list of the source domain and target domain with their related context is listed individually of both the countries before conducting the interpretational analysis of the social representation of each metaphor. After analyzing each war metaphor closely, the study will look into the reasons behind identified military metaphors.

After listing all the metaphors, SIX source domain metaphors from speeches of USA namely WAR, WARTIME PRESIDENT, ENEMY, SOLDIERS, HOMEFRONT, VICTORY have been critically examined in a way of ideological construction of the speaker. Similarly, SIX source domains drawn out from the speeches of the UK are listed out, WAR, 
ENEMY, WARTIME GOVERNMENT, FRONTLINE, SOLDIERS, BLITZ SPIRIT will be analyzed accordingly. These metaphors will also be analyzed accordingly to explore certain ideologies behind using them.

\section{FINDINGS AND DISCUSSION}

The data is analyzed with the help of source domains and target domains. The selected speeches are carefully read, reread to figure out the cognitive (target domains) and the source domains. This shows the speaker's use of entailments in talking about the same phenomenon i.e. Coronavirus.

\section{List of Source domains in speeches of United Kingdom}

Table 1: Speeches of the United Kingdom

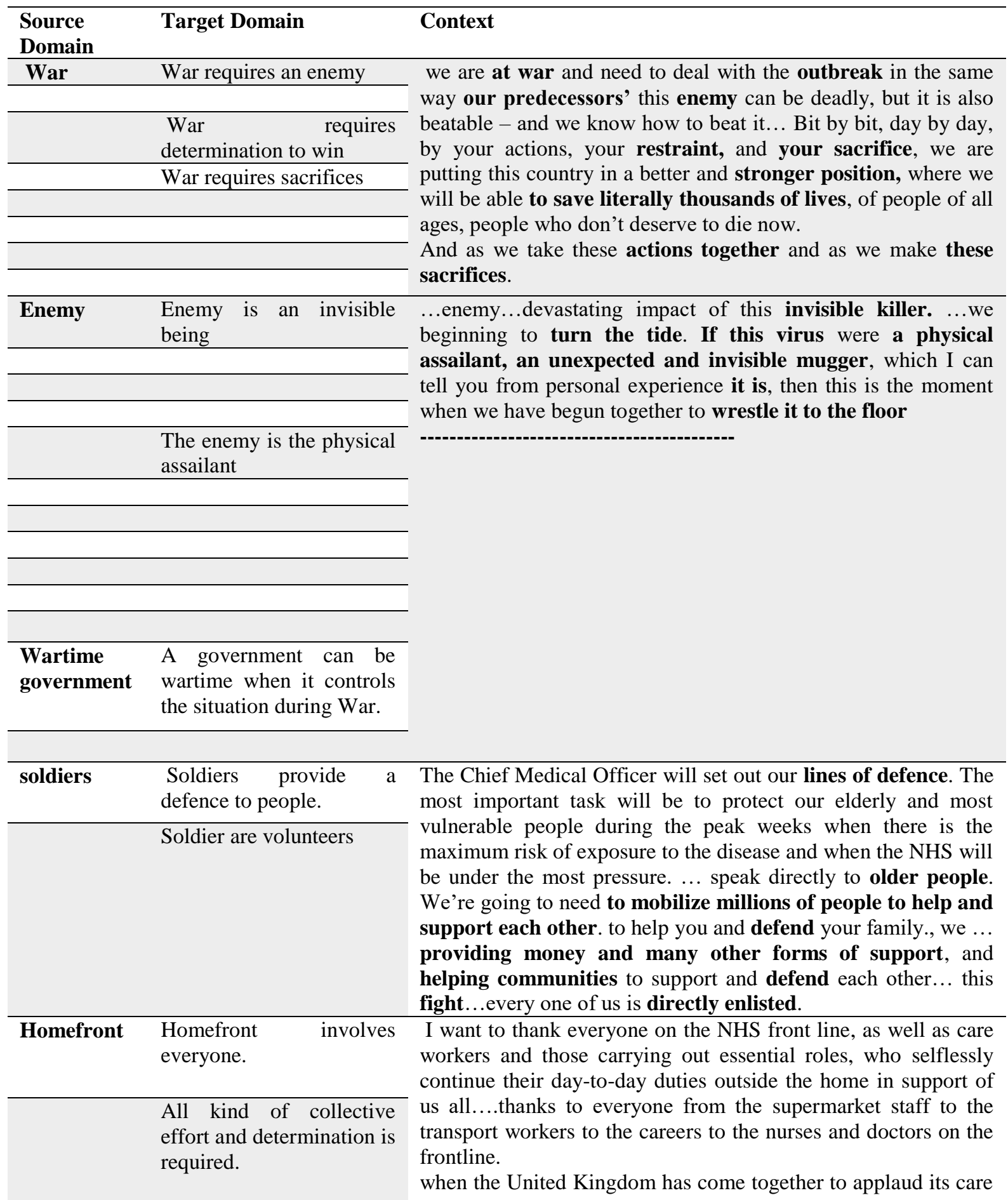


Homefront requires and essential workers will be remembered as an expression of medicines and other our national spirit in $1940 \ldots$ better days will return: we will be materials. with our friends again; we will be with our families again; We will meet again...

And that is how, by a mixture of determined, collective action and scientific progress... we will turn the tide of this disease and beat it together. And so, it's vital that we in Government stand behind ... saving literally thousands of lives by defeating this virus. now we are going to defeat this disease ...national effort

\begin{tabular}{ll}
\hline Blitz Spirit & A national spirit of 1940 \\
\hline & $\begin{array}{l}\text { Economy growth is } \\
\text { attained. }\end{array}$ \\
\hline
\end{tabular}

National spirit is required to beat the enemy to slow the spread by reducing unnecessary social contact.... the UK economy is going to bounce back.

Together we are tackling this disease... if we remain united and resolute, we will overcome it. ... when the United Kingdom has come together to applaud its care and essential workers will be remembered as an expression of our national spirit in $1940 \ldots$. better days will return: we will be with our friends again; we will be with our families again; WE WILL MEET AGAIN. Thanks to all .... national fight-back against coronavirus.

\section{Source: See Appendix A}

\section{Metaphorical analysis of speeches in the United Kingdom}

The Prime minister of the UK has employed WAR metaphors in his speeches. His public and press briefings are analyzed metaphorically and this helps to bring out entailments that support the listed military metaphors.

\section{Metaphor identification.}

\section{a. War}

The president of the UK has activated the metaphor of WAR in his different press and public conferences. In his press conference on March 12, 2020, he states that

"We are at war with the enemy and need to deal with this outbreak in the same way our predecessors"

This speech has made use of the words War and Enemy. The UK has also given reference to World War 2 in his speech and compared this outbreak with the past war. See E2 in Appendix A.

\section{b. Enemy}

The UK public addressing's activated the entailments of the enemy when the enemy is referring to a deadly killer, physical assailant, invisible killer.

"Yes, this enemy can be deadly, but it is also beatable - and we know how to beat it."'See E7(Appendix A)

Similarly, he calls the enemy to be a physical assailant, invisible killer, as he states that

"This virus is a physical assailant, an unexpected and invisible mugger, which I can tell you from personal experience it is, then this is the moment when we have begun together to wrestle it to the floor". E5 See (Appendix A)

\section{c. Wartime government}

The UK has called his government a WARTIME government. This reflects that the UK government is relating its present government with the past government of world war 2.

"We must act like any wartime government and do whatever it takes to support our economy" like we did in an unprecedented time during world war II". E3 See (Appendix A)

\section{d. Soldiers}

In traditional wars soldiers fight with the enemy to defend their country, they fight with it and defeat it. In the UK the government calls teachers, public servants, police officers, scientists, and doctors' soldiers who are fighting to beat this virus.

"I want to thank everyone in the NHS, the front line of the fight against coronavirus. And of course, all our public services. Our teachers and our school staff, the transport workers, police officers, and everyone who is keeping this country going. "E4 (See Appendix A)

It is also important to mention that soldiers are the ones who provide a defence to people without caring about their own lives. This war metaphor of soldiers is connected with other related information of defending the public from the harms of the virus. The older people are particularly addressed to keep them safe from being contacted with viruses. 
"The Chief Medical Officer will set out our lines of defence. We have to deploy these at the right time to maximize their effect. The most important task will be to protect our elderly and most vulnerable people during the peak weeks when there is the maximum risk of exposure to the disease. "E7 (See Appendix A)

He also mentions that his soldiers are volunteers, all ordinary people who come forward to fight for their country. During the traditional war, soldiers are assigned particular duties. Referring to this, during Covid 19 pandemic in the UK, 405000 volunteers have positioned themselves to serve people during the spread of the virus. As prime minister thanks all volunteers in his public speech, (25 March. 2020)

"I can tell you that in just 24 hours 405,000 people have responded to the call. They will be driving medicines from pharmacies to patients. They will be bringing patients home from the hospital. Very importantly they'll be making regular phone calls to check on and support people who are staying on their own at home. they will be crucial in the fight against this virus. That is already - in one day - as many volunteers as the population of Coventry" E8 (See Appendix A)

\section{d. Home front}

Like the USA, The UK has also employed the homefront metaphor for people at home to support people at frontline. This involves people who are at home to stay isolated and at home. "We will be asking everyone in the household to stay at home”.E3 See App. A

At another place, the prime minister said:

"That our incredible doctors and nurses and healthcare staff have been able to shield all of us from an outbreak that would have been far worse.' E7 See Appendix A

\section{e. Blitz spirit}

The Blitz spirit is referred to as a national spirit shown by Britons in the 1940 war. In one of Queen Elizabeth's speeches, she refers to the song of national unity "we will meet again" sung during the 1940 war to the current situation of COVID 19. As she said:

"We should take comfort that while we may have more still to endure, better days will return: we will be with our friends again; we will be with our families again; we will meet again”. E9 See Appendix A

\section{Metaphor interpretation}

In this stage, the reader will interpret the relationship between the text and the metaphors used by the speaker and try to uncover the hidden cognitive and pragmatic elements lying behind the conceptual metaphors (Charteris-Black,2004).

The metaphors used by the Prime minister and Queen in public and press addresses are responsible to convey very significant ideologies. Calling a virus, killer, wrestle it to the floor, physical Assailant, deadly killer, the enemy the prime minister reveals many different nouns for the virus. These nouns are metaphorical as it is impossible to look at the virus with a naked eye. Moreover, Wars require military leaders to lead all the struggles endured by the soldiers. The UK government calls itself a wartime government. They keep using War metaphors systematically in their public messages. By using each metaphor they refer back to WORLD WAR II. Where Britons had shown real national spirit to win the war. Using Soldiers as a war metaphor in their speeches on COVID 19 reflects the target domain of employing volunteers as soldiers, and all public servants, teachers, doctors' nurses as their soldiers who are confronting the disease and providing defence against the virus. The prime minister is specifically concerned for older people to stay safe from this virus. He has shown special concern for older individuals in his messages.

It is also obvious that during wars, along with soldiers, there are the people at HOMEFRONT, who self-sacrifice to support people at FRONTLINE. Using the metaphor of soldiers might confuse with taking Home front as a metaphor, as it is obvious in Johnson's speech on Coronavirus where he relates this pandemic to WORLD WAR II 'Unprecedented time during WORLD WAR II' (E3 Appendix A). He relates that there are areas during the war which are apart from the military operation, that is the home front. Where people support through self-sacrifice by staying at home and avoiding physical contact to save lives.

"We now need to impose physical distance between ourselves, we must at the same time have closer social support for each other."( E1 Appendix A)

All soldiers and other citizens of the UK according to the prime minister and Queen Elizabeth must show 'Blitz spirit' in this difficult crisis. The United Kingdom prime minister and Queen give reference to past WAR fought during 1940 and expect the citizens to show the same national spirit that they showed in the past. The Queen reminds the nation of the song sung during wartime in 1940, "WE WILL MEET AGAIN".

The aim and objective behind this reference to demand the public to remain united and calm in this difficult situation.

"We are now engaged in a new struggle against the coronavirus which demands the same spirit or national endeavor." (E9 See Appendix A) 
Similarly, she says that "it's by this combination of ruthless, determined, collective action, scientific action, progress that we're already seeing that WE WILL SUCCEED. (E9 See Appendix A)

The prime minister is very determined to overcome the ongoing situation of the battle against Coronavirus,

“...and I want to reassure you that if we remain united and resolute, then we will overcome it." (E8 Appendix A)

Similarly, he mentions in one of his speeches that

"Of course, I am confident that, in time, the UK economy is going to bounce back."(E6 See Appendix A)

As this whole battle with coronavirus is considered a war, then this war should end with the elimination of the disease, the revival of health issues of corona patients, making a specific Vaccine to treat COVID 19 for future corona patients. But for the British government, their war must end with economic revival, meeting the friends and loved ones, and this confirms from the queen's words "WE WILL MEET AGAIN" (E9 Appendix A).

\section{Metaphor explanation}

This third stage will discuss the relevance of the metaphor with the context. By using metaphors, the element of persuasion invokes readers to identify the ideological and rhetorical motivations. Also, it helps in the identification of discursive functions of the metaphors employed in the study.

The UK Prime Minister has used WAR metaphors in their speeches, calling Coronavirus, an invisible enemy, invisible killer, invisible mugger to wrestle it to the floor, deadly enemy, to persuade readers to think that in wars enemies are usually seen and visible. This fight with COVID 19 is virtual by nature. As George Lakoff (1980) has pointed out, the metaphors we choose both reflect our prejudices and influence our approach to the world. So here Johnson's use of mugger, killer reflects his perception of the virus. He further names his government a WARTIME GOVERNMENT, which reveals how his mind is influenced by the wartime situation, relating this war with WORLD WAR II. Furthermore, his employing the target domain of volunteers, public servants, my British people, National challenge directly invoking the idea of his nationalism. The UK has used War metaphors less effectively as compared to other countries. Regarding winning the battle with coronavirus, he uses the words beat, fight, combat, defeat, to win the battle. For the British government, the national spirit is an important factor to ensure them winning the battle against coronavirus. It has been mentioned significantly in the UK speeches by the Prime minister and the Queen to bring the flourished economy back to its former state is the success of this war. They evoked the" Blitz Spirit" of the Second World War in their press and public meetings, through this they remind all Britons of the past national and collective efforts that helped them win the battle.

"We will get through this, this country will get through this epidemic, just as it has got through many tougher experiences before if we look out for each other and commit wholeheartedly to a full national effort.

Talking to the press and general public, he keeps reminding them to self-sacrifice to support the people at FRONTLINE. Although he does not convey any racial statement and blame any country for this epidemic.

\section{List of Source Domains in speeches of United States}

Table 2: Speeches of President of USA

\begin{tabular}{|c|c|c|}
\hline $\begin{array}{l}\text { Source } \\
\text { Domain }\end{array}$ & Target domain & Context \\
\hline \multirow[t]{4}{*}{ War } & War requires an enemy & \multirow[t]{4}{*}{$\begin{array}{l}\text { And to this day, nobody has seen anything like what they were able to do } \\
\text { during World War II. And now it's our time. We must sacrifice together } \\
\text { because we are all in this together and we will come through together. } \\
\text { It's the invisible enemy. That's always the toughest enemy: the invisible } \\
\text { enemy. But we are going to defeat the invisible enemy. I think we are } \\
\text { going to do it even faster than we thought. And it will be a complete } \\
\text { victory it will be a total victory. }\end{array}$} \\
\hline & War requires soldiers & \\
\hline & $\begin{array}{l}\text { War requires sacrifices } \\
\text { on the home front }\end{array}$ & \\
\hline & War requires victory & \\
\hline \multirow[t]{3}{*}{ Enemy } & Enemy is monster & \multirow{3}{*}{$\begin{array}{l}\text { It's not attacking - the enemy is attacking } \mathbf{1 4 4} \text { countries at this moment. } \\
\text { 144. That's unthinkable. That's never been anything like this and it's } \\
\text { vicious. It's vicious. Like our earlier, very aggressive actions to China } \\
\text { this measurable saved countless lives. The onslaught of the Chinese virus } \\
\text { is not your fault }\end{array}$} \\
\hline & Enemy is foreign & \\
\hline & Enemy is aggressor & \\
\hline $\begin{array}{l}\text { Wartime } \\
\text { president }\end{array}$ & $\begin{array}{l}\text { War requires the leader } \\
\text { to be military, not a } \\
\text { civilian }\end{array}$ & $\begin{array}{l}\text { I am a wartime president. This is war. This is a war. A different kind of } \\
\text { war than we have ever had. }\end{array}$ \\
\hline
\end{tabular}




\begin{tabular}{|c|c|c|}
\hline Soldiers & $\begin{array}{l}\text { War makes } \\
\text { professionals } \\
\text { soldiers } \\
\text { War makes ordinary } \\
\text { people into heroes }\end{array}$ & $\begin{array}{l}\text { We are at war with an invisible enemy, but that enemy is not the norm } \\
\text { for the spirit and receive after American people - it cannot overcome } \\
\text { the dedication of American doctors, nurses, and scientists - and it } \\
\text { cannot beat the love, patriotism, and determination of our citizens. } \\
\text { Strong and united we will prevail. This afternoon I'll be meeting with } \\
\text { nurses on the front lines of the battle against the virus. They are true } \\
\text { American heroes. } \\
\text { I want to take a moment of thanks. I want to take a moment to thank the } \\
\text { everyday heroes who are making our vast effort against a virus possible. } \\
\text { And thank you to them - thanks also to the hard-working men and } \\
\text { women who are federal express, UBS, the United States Postal Service } \\
\text { is, and truckers who are maintaining our supply chains and supply } \\
\text { lines. }\end{array}$ \\
\hline \multirow[t]{3}{*}{ Homefront } & $\begin{array}{l}\text { Homefront } \\
\text { everyone }\end{array}$ & \multirow{3}{*}{$\begin{array}{l}\text { We are announcing new guidelines for every American to follow over } \\
\text { the next } 15 \text { days the combat the virus. Each and every one of us has a } \\
\text { critical role to play in stopping the spread and transmission of the virus. } \\
\text { They know they are getting through the prices and will require an all of } \\
\text { American approach, and that's very important. I ask all Americans to } \\
\text { band together and support your neighbors by not holding unnecessary } \\
\text { amounts of food and essentials together. we will stay strong and } \\
\text { overcome this challenge }\end{array}$} \\
\hline & $\begin{array}{l}\text { Home front requires } \\
\text { collective effort and } \\
\text { collective sacrifice }\end{array}$ & \\
\hline & $\begin{array}{l}\text { Weapons and materials } \\
\text { must be produced and } \\
\text { preserved }\end{array}$ & \\
\hline \multirow[t]{3}{*}{ Victory } & War must be won & \multirow[t]{3}{*}{$\begin{array}{l}\text { As long as I am your president, you can feel confident that you have a } \\
\text { leader who will always fight for you and I will not stop until we win. } \\
\text { This will be a great victory that is going to be a victory. Normal life will } \\
\text { return. And I think the economy will rebound very very strongly but } \\
\text { right now, in the midst of a great national trial, Americans must remain } \\
\text { united in purpose and focus on victory. Then we win the war against the } \\
\text { virus. We want to make sure those companies are ready to charge forward- } \\
\text { not that they have been disbanded because we were Pennywise and dollar } \\
\text { foolish. I think it's going to be a tremendous day anyway when we win } \\
\text { this war - and we will win the war. we want to win the war with as few } \\
\text { - if you look at it - just that as possible they want to have a few numbers } \\
\text { of deaths as possible. }\end{array}$} \\
\hline & $\begin{array}{lll}\text { Some deaths } & \text { are } \\
\text { possible. } & & \end{array}$ & \\
\hline & $\begin{array}{l}\text { Economic strength is } \\
\text { victory. }\end{array}$ & \\
\hline
\end{tabular}

Source: See Appendix B

\section{Metaphorical analysis of war metaphors in the United States}

\section{Metaphor identification}

The US president has used war metaphors exclusively in all his meetings with the press and the nation. He has activated the war metaphor in his speech early in March., Trump argued:

"Every generation of Americans has been called to make shared sacrifices for the good of the nation. In World War Two, young people in their teenage years volunteered to fight. They wanted to fight so badly because they love our country. Workers refused to go home and slept on factory floors to keep assembly lines running. And, you know, the number of ships that they built during World War Two, to this day has never-nothing like that has ever been equal. They were doing ships on a-daily. Nobody has ever seen anything like it. To this day, nobody has seen anything like what they were able to do during World War Two. And now it's our time. We must sacrifice together because we are all in this together and we'll come through together. It's the invisible enemy. That's always the toughest enemy: the invisible enemy. But we're going to defeat the invisible enemy. I think we're going to do it even faster than we thought. And it will be a complete victory. It'll be a total victory". U5 (See Appendix B)

So, from the speech that Trump has reminded the public of the memories of World War II, and also, he reminds of the role of the citizens during the war, on the home front. Trump has activated the war metaphor in the above speech. By making associations with World War II, Trump has called an invisible enemy for coronavirus that is present in the world globally. So, in his efforts to fight with COVID 19, to complete this metaphor of war, a series of entitlements are created. Because metaphors demand cognitive and affective associations, metaphors encourage the rhetor to attend not 
only to the definition of the struggle, and that the struggle is a WAR, but what else is required for this WAR is also needed. The other source domains are, WARTIME president, ENEMY, HOMEFRONT, SOLDIERS, VICTORY.

Through this speech, it can be seen that all war metaphors are closely contextualized in the context giving meaningful meaning in the development of a WAR with coronavirus.

\section{A. Enemy}

The United States of America has kept calling this virus a CHINESE Virus, directly hitting China responsible for this virus. Viruses do not have any identities so naming the virus or linking with any countries brings out significant ideological perspectives of the speaker. Here are few examples from his speech.

"I would like to begin by announcing some important developments in our war against the Chinese virus"

We'll be invoking the Defence Production Act, just in case we need it. In other words, I think you all know what it is, and it can do a lot of good things if we need it." U3(Appendix B).

In another place, Trump argued,

"The onslaught of the Chinese Virus is not your fault!" U3(Appendix B).

\section{B. Wartime president}

Trump has associated his position of being a "WARTIME PRESIDENT". This is used as metaphorically as war requires leaders to be military but they must not be a civilian or leader. He states: "I look at it, I view it as, in a sense, a wartime president. I mean, that's what we're fighting.’U7 (See Appendix B)

American president looks at himself on wartime footing as president during WAR with this virus.

\section{Soldiers}

Soldiers are people who fight in a battle to save the country, this term is used for all nurses, policemen, doctors, scientists, and all who are fighting to save people from this virus. They are called soldiers because they are serving COVID 19 patients, regardless of their health and life. They are fighting at the forefront.

"I'll be meeting with nurses on the frontlines of the battle against the virus. They are true American heroes. They want to get it done. They're incredible people. . . They're very brave. They're taking a lot of risks. incredible." U6(See Appendix B)

\section{Homefront}

The speeches conducted by the USA have used HOMEFRONT instead of FRONTLINE as the frontline is demanded by the soldiers in the war field. The President of the USA has announced responsibilities and duties to all people the citizens of America to be involved and engaged in terms of fighting with this virus. He specifically addresses the people living in the home to take necessary precautions to stay safe and also gives instructions regarding social distancing.

He urged the citizens to self-sacrifice to support people at FRONTLINE. At one place he suggests, "This afternoon, we're announcing new guidelines for every American to follow over the next 15 days as we combat the virus. Every one of us has a critical role to play in stopping the spread and transmission of the virus"

\section{E. Victory}

Victory is chosen as a source domain that has cognitive and pragmatic entailments in the speech of war. The president of the USA reassures his citizens that their fight with coronavirus will end up in victory. As every war result in failure or a victory. The president was confident that as a leader his fight with coronavirus will bring them victorious moments soon. As it is reflected in his speech:

"America continues to mobilize every segment of our society to turn the tide in the battle against the virus. I want Americans to know that we will get through this challenge. The hardship will end; it will end soon. Normal life will return. And our economy will rebound very, very strongly. But, right now, in the midst of this great national trial, Americans must remain united in purpose and focused on victory."

\section{U2 (See Appendix B)}

So, victory is identified as a cognitive and pragmatic source domain in terms of using WAR as a leading metaphor in all US president speeches.

\section{Metaphor interpretation}

The traditional war requires an enemy, the state actor declares war against an aggressor state. However, in the case of Coronavirus, there is not a state actor attacking the USA. Like in Johnson's government (1984), A war was declared against poverty and in the case of Reagan's declaration of war on drugs, the enemies in the war were poor people and drug abusers respectively. Here the country declares war against a Virus that does not have any physical appearance or 
has any will to engage in any aggression. Calling coronavirus an enemy and "INVISIBLE ENEMY" is also ironic as WAR is usually done with an enemy which is visible. so here in one of the speeches in the mid of March 2020, the president of the USA states that "it's now attacking - the enemy is attacking 144 countries at this moment."U1 (Appendix B).

Here it sounds ridiculous that a single ENEMY would choose to attack 144 countries at the same time. At another point, it is claimed that the virus is VICIOUS. This reflects the studies conducted in the past claiming that their enemy is SAVAGE (Ivie, 1984). So, calling Virus an Enemy seems to vitiate the metaphor. As every WAR demands that the enemy is definable.

Later, in the public statements, the president has stated "I would like to begin by announcing some important developments and out of our account as the Chinese Virus."U3 (Appendix B)

Here the declaration of WAR against a virus associated with the nation-state, China is held responsible for spreading this virus. This statement seems to complete the target domain choosing the foreign ENEMY is China. Hence this seems to complete the war metaphor. This shift from coronavirus to Chinese virus has large implications from a scientific term to our accusative term assigning responsibility for the occurrence of virus.

Later the use of WARTIME PRESIDENT also appears ironic to the audience in which the president is naming his position and titled himself as a wartime president. Wars demand leaders to be military, not civilians or leaders. Revealing this title, it can be said the president is confident and authoritative to fight all kinds of WARs in general, war with coronavirus in particular.

In traditional war, nations are fought at an abstract level. But at a practical level, war is waged among men and women of both nations. Here using metaphor SOLDIERS for those who help in fighting with the virus and these Soldiers are medical workers, delivery persons, restaurant and grocery store, workers. "I want all Americans to understand: we are at war with an invisible enemy, but that enemy is no match for the spirit and resolve of the American people.......It cannot overcome the dedication of our - and it cannot beat the LOVE, PATRIOTISM, and DETERMINATION of our citizens. Strong and United, WE WILL PREVAIL!” U5 (Appendix B)

In this public speech delivered by Trump, the auditor gets a deep insight into the idea of calling all doctors, nurses, and scientists as soldiers. The war is fought with an ENEMY and that ENEMY is encountered by doctors, nurses, and scientists that make them real soldiers. Calling them Soldiers is not based on health sciences, but on their LOVE, PATRIOTISM, and DETERMINATION to the nation. He also calls them real heroes as stated in the following statement,

"I want to take a moment to thank the everyday heroes who are making our vast effort against the virus possible." U6 (Appendix B)

These statements help in completing the entailments for choosing SOLDIER as a metaphor.

Another metaphor, HOMEFRONT, involves all people or citizens to support people on FRONTLINE.

This relates to self-sacrifice by staying at home and collective efforts from the nation.

As it is mentioned above, world war $\mathbf{2}$ is invoked as a model for the WAR on COVID 19. Then it is very reasonable to expect him to call state's arguments are governments and give them equal responsibilities to focus on the front lines. The president and his speeches largely fail to fulfill this expectation. He has not mentioned any meaningful participation in the efforts against COVID-19 to most of the public. he disconnects people, municipalities, and states from this war. Similarly, hoardings are taken as a positive step during WAR but the president in his speech has criticized people for hoarding items.

'I signed an executive order ... to prohibit the hoarding of vital medical equipment and supplies such as hand sanitizers, face masks, and personal protective equipment".U7 (see Appendix B)

Another critical role on the HOMEFRONT is participating in the workforce. People are encouraged for their collective sacrifice but this sacrifice is not demanded from people but from companies for which they work. It is urged by companies to stay open, specifically companies of food services and manufacturing medical items to facilitate people. There is another point that is also not parallel to calls in World War 2 is to call people to join the workforce. The military people who go to battlegrounds are replaced with ordinary people. But here the entailment does not fit well as the president's statement suggests to stay at home and keep social distancing. This connects to how people at home and isolated can contribute towards fighting a WAR. the last metaphor VICTORY is connected with the collective sacrifice and the actions of soldiers on the front line and the citizens on the HOMEFRONT. These all entailments help complete the War metaphor along with the last entitlement that is victory and we must know that when we have attained a victory. Every war ends with a victory. In this coronavirus war, the victory should constitute the elimination of this disease. As the President of the USA states in his speech: 
"For those worried and afraid, please know: As long as I am your President, you can feel confident that you have a leader who will always fight for you, and I will not stop until we win. This will be a great victory. This is going to be a victory..." U3(See Appendix)

At another place, he says that :

"I want Americans to know that we will get through this challenge. The hardship will end; it will end soon. Normal life will return. And our economy will rebound very, very strongly. But, right now, in the midst of this great national trial, Americans must remain united in purpose and focused on victory." U5

This implies that the victory does not demand the elimination of the disease, health issues of the people but the economic growth and economic revival. For him, saving the economy is far important than saving the lives of people.

\section{Metaphor explanation}

These above metaphorical representations suggest that The USA has self-portrayed its position on this WAR on COVID 19. Calling CHINA VIRUS, WUHAN VIRUS, CHINESE VIRUS has depicted the country's racist ideology towards China. This may have reflected the past political tensions with China on Trade and other metropolitan issues. Also, labeling himself as WARTIME PRESIDENT also reflects his own strong, powerful and authoritative position in the world. Similarly, victory ends with killing or defeating the enemy. But in this war against the virus, the victory results from the economic revival of the country.

\section{FINDINGS}

Metaphoric language has a great influence on our cognitions as $\operatorname{Hart}(2010$, p. 126) contends that metaphor is linked with our conceptual system which is utilized to make sense of our experience. This study has described how metaphorical riched discourse reflects on how people see, think, and act in the world(Ahmad,2021). Source domain gives the rich notions that are associated with target domains (Charteris-Black,2004).

After discussing the source domains of WAR, by two countries namely the USA and the UK, it can be significantly said that the US president has adopted War source domain to construct the ideology of being strong, more powerful than other nations and showing his extreme authoritative (WARTIME PRESIDENT) positions in all statements about this fight against coronavirus(Bates,2020). He has been very racially inclined and directly blames China for this disease, (CHINESE VIRUS). America has been in activities to wage wars against other countries i.e. Iraq, Iran. Afghanistan holds its supremacy over all nations and intends to remain powerful and authoritative globally. The president also shows a nationalist approach in his statements by using the words, LOVE, DETERMINATION, UNITED, which reveals solidarity to Americans. He also makes use of WAR metaphors, SOLDIERS, VICTORY. ENEMY, HOMEFRONT, WEAPONS more prominently in his speeches than the British government. He calls the Enemy vicious, and invisible. Hence, it can be seen that the use of war metaphors in talk help constructing ideologies that further highlighting politicians' mindset and perceptions (McHugh \& Chrysler, 2010).

On the other hand, the British Prime Minister has also used WAR metaphors i. e ENEMY, SOLDIERS, HOMEFRONT, BLITZ SPIRIT, and the Queen in their statements, use fewer WAR metaphors than the USA. They have illustrated references to the BLITZ SPIRIT in their speeches to invoke national unity and support to win the war. UK's speeches imply the nationalistic ideologies for Britons to remain calm and united in this difficult situation. Also, talking about setting the defence lines, he talks more about older people preferably people of other age groups. He turns volunteers into soldiers. Also, he shifts his entailment from enemy to the killer, physical assailant, wrestles it to the floor. Moreover, none of the Queen's message and PM messages holds responsible any country for this virus. As blamed by America calling it the WUHAN VIRUS.

The two countries have used few similar source domains i.e. WAR, HOMEFRONT, ENEMY, and while few different source domains are also employed, as for USA, WARTIME PRESIDENT, VICTORY, and in the UK, it has used, WARTIME GOVERNMENT, BLITZ SPIRIT

\section{CONCLUSION}

This comparative study has analyzed WAR metaphors taken as source domains to study how these conceptual metaphors help in developing different ideologies of the selected speeches by two countries. Charteris-Black (2004) framework for critical metaphor analysis (CMA) has been employed to study the analysis of the metaphors in the speeches about the COVID 19 pandemic. It is important to mention that countries use war metaphors in their talk when they aim to make their people realize the intensity of the disease. The speeches delivered from March $1^{\text {st }}, 2020$ till April 10 ${ }^{\text {th }}, 2020$, are taken purposively for the analysis. It has been observed that USA speeches are found with more WAR metaphors as compared to UK speeches. The USA has made use of strong words related to military language and remains persistent in using military language metaphorically throughout his speeches. He remains authoritative and dominant in his choice of words, which also reveals the notion of nationalism for his people. The president also adopts the strategy for being racist in his comments about blaming other countries for this pandemic whereas The United Kingdom has employed fewer entailments of WAR metaphors. it is also obvious that the prime Minister shifts his language from military to common 
language. By using, 'Enemy' to 'Physical Assailant' 'deadly Killer'. The statements reflect more of nationalist ideology referencing BLITZ SPIRITi.e the song, (sung in1940 World War), "WE WILL MEET AGAIN". The choice of words used by the UK shows solidarity and a sense of responsibility to curb the ongoing situation in the country.

\section{LIMITATION AND STUDY FORWARD}

The current study provides a cross-sectional analysis of public speech data. However, longitudinal data analysis may complement this study by covering a wider chronological space and analysis of more diverse data.

\section{ACKNOWLEDGEMENT}

The authors are deeply indebted to Professor Noah Lane for his valuable comments on an earlier draft of this article. We also acknowledged the tremendous contribution of the anonymous reviewers of the Journal of Humanities and Social Sciences for their incisive comments.

\section{AUTHORS CONTRIBUTION}

The first and second authors developed the focus of the article, its theoretical framing and provided data for analysis. The third and fourth authors analysed the data guided by the theoretical framing. The fifth author contributed to the Findings section and wrote the abstract of the article.

\section{REFERENCES}

1. Abdel-Raheem. A, (2021) Reality bites: How the pandemic has begun to shape the way we, metaphorically, see the world. Discourse \& Society, 26. https://doi.org/10.1177/09579265211013118

2. Bates, B. R. (2004). Audiences, metaphors, and the Persian Gulf War. Commun. Stud. 55, $447-463$. https://doi.org/10.1080/10510970409388631

3. Bates, B. R. (2020) The (In)Appropriateness of the WAR Metaphor in Response to SARS-CoV-2: A Rapid Analysis of Donald J. Trump's Rhetoric. Front. Commun, 5, 50. https://doi.org/10.3389/fcomm.2020.00050

4. Charteris-Black, J. (2004). Corpus approaches to critical metaphor analysis. New York Palgrave Macmillan. https://doi.org/10.1057/9780230000612

5. Charteris-Black, J. (2005). Politicians and rhetoric: The persuasive power of metaphor. London: Palgrave Macmillan. https://doi.org/10.1057/9780230501706

6. Edelman, M. (1971). Politics as Symbolic Action. Mass Arousal and Quiescence. Chicago, IL: Markham.

7. Flusberg SJ, Matlock T, Thibodeau PH (2018). War metaphors in public discourse. Metaphor and Symbol. https://doi.org/10.1080/10926488.2018.1407992

8. Hart, C. (2010). Critical discourse and cognitive science: New perspectives on immigration discourse. Basingstoke: Palgrave Macmillan. https://doi.org/10.1057/9780230299009

9. Lowe, N. K. (2018). Words matter. Journal of Obstetric, Gynecologic \& Neonatal Nursing, 47(1),1-2. https://doi.org/10.1016/j.jogn.2017.11.007

10. Ivie, R. L. (1984). Speaking “common sense” about the Soviet threat: Reagan's rhetorical stance. West. J. Speech Commun. 48, 39-50. https://doi.org/10.1080/10570318409374140

11. Koller, V. (2005) 'Critical Discourse Analysis and Social Cognition: Evidence from Business Media Discourse', Discourse \& Society 16: 199 science, 4(2). https://doi.org/10.1207/s15516709cog0402_4

12. Lakoff, G., and Johnson. (1980). Metaphors We Live By. Chicago, IL: University of Chicago Press.

13. Lakoff, G. (1993). The Contemporary Theory of Metaphor', in A. Ortony (ed.) Metaphor and Thought, 2nd ed, pp. 202-51. Cambridge: Cambridge University. https://doi.org/10.1017/CBO9781139173865.013

14. Lakoff, G. (2004). Don't Think of an Elephant! Know Your Values and Frame the Debate. White River Junction, VT: Chelsea Green.

15. Machin, D., \& Mayr, A. (2012). How to do critical discourse analysis: A Multimodal Introduction. Los Angeles: Sage.

16. Mirghani, S. (2011). The war on piracy: analyzing the discursive battles of corporate and governmentsponsored anti-piracy media campaigns. Crit. Stud. Media Commun, 28, 113-134. https://doi.org/10.1080/15 295036.2010 .514933

17. Semino, E. (2002). Ä Sturdy Baby or a Derailing Train? Metaphorical Representations of the Euro in British and Italian Newspapers, Text, 22, 107-39. https://doi.org/10.1515/text.2002.001

18. Semino, E. and Masci, M. (1996). Politics is Football: Metaphor in the Discourse of Silvio Berlusconi in Italy. Discourse \& Society, 7, 243-269. https://doi.org/10.1177/0957926596007002005

19. Semino, E. (2021). Not Soldiers but Fire-fighters - Metaphors and Covid-19. Health Communication, 36(1), 50-58, https://doi.org/10.1080/10410236.2020.1844989

20. Sudajit. M. (2017). A Critical Metaphor Analysis of Disability Identity and Ideology in the Thai Undergraduates' Home for Children with Disabilities Website Project. https://doi.org/10.7575/aia c.alls.v.8n.5p.79

21. Van Dijk, T.A. (1998) Ideology. A Multidisciplinary Approach. London: SAGE. 
22. Van Dijk, T.A. (2000) 'Ideologies, Racism, Discourse: Debates on Immigration Ethic Issues', in J. Ter Wal and M. Verkuyten (eds) Comparative Perspectives on pp. 91-116. Aldershot: Ashgate. https://doi.org/10. 4324/9781315196374-5

23. Van Dijk, T.A. (2001) 'Discourse, Ideology and Context', Folia Linguistic XXX/ 1-pp. 11-40. https://doi.org/10.1515/flin.2001.35.1-2.11

24. Panzeri F, Di Paola S, Domaneschi F (2021) Does the COVID-19 war metaphor influence reasoning? PLoS ONE, 16(4). https://doi.org/10.1371/journal.pone.0250651

25. Chiang.Y.W \& Duann.F.R.(2007) Conceptual metaphors for SARS: war with whom? Source: discourse \& Society, 18(5). https://doi.org/10.1177/0957926507079631

26. Guo, S. (2013). Metaphor studies from the perspective of critical discourse analysis: A case study of business acquisition. Theory and Practice in Language Studies, 3(3), 475-481. https://doi.org/10.4304/tpls.3.3.475-481

27. Mukunth V. If We're at 'War' With the New Coronavirus, We're Doing It Wrong. The Wire 2020 April 15 [Cited 2020 October 6]. Available from: https://thewire.in/government/coronavirus-language-warmasculinityclimate-change-righ

28. Thibodeau PH, Hendricks RK, Boroditsky L. How linguistic metaphor scaffolds reasoning. Trends in cognitive sciences, 21(11), 852-63. https://doi.org/10.1016/j.tics.2017.07.001

29. Smith, C. A., Johnston-Robledo, I., McHugh, M. C. and Chrisler, J. C. (2010). Words matter: The language of gender. Handbook of Gender Research in Psychology, 361-377. https://doi.org/10.1007/978-1-4419-14651 1_ 18

30. Wise A. Military Metaphors Distort the Reality of COVID-19. Scientific American. 2020 April 17 [cited 2021 January 30]. Available from: https://blogs.scientificamerican.com/observations/militarymetaphors-distort-thereality-of-covid-19/

\section{Data retrieval resources}

The data is retrieved from the government official websites of both countries.

\section{1) The websites for United Kingdom}

https://www.gov.uk/

\section{2) The Websites for United States}

https://www.whitehouse.gov/briefings-statements/

\section{APPENDICES \\ APPENDIX A}

\section{LIST OF SPEECHES OF UK}

\begin{tabular}{lll}
\hline $\begin{array}{l}\text { S } \\
\text { No. }\end{array}$ & Speeches & Web links \\
\hline 1 & E1 & $\begin{array}{l}\text { https://www.gov.uk/government/speeches/pm-statement-at-coronavirus-press-conference-3- } \\
\text { march-2020 }\end{array}$ \\
\hline 2 & E2 & https://www.gov.uk/government/speeches/pm-statement-on-coronavirus-12-march-2020 \\
\hline 3 & E3 & https://www.gov.uk/government/speeches/pm-statement-on-coronavirus-16-march-2020 \\
\hline 4 & E4 & https://www.gov.uk/government/speeches/pm-statement-on-coronavirus-17-march-2020 \\
\hline 5 & E5 & https://www.gov.uk/government/speeches/pm-statement-on-coronavirus-18-march-2020 \\
\hline 7 & E6 & https://www.gov.uk/government/speeches/pm-statement-on-coronavirus-20-march-2020 \\
\hline 8 & E8 & $\begin{array}{l}\text { https://www.gov.uk/government/speeches/pm-address-to-the-nation-on-coronavirus-23- } \\
\text { march-2020 }\end{array}$ \\
\hline 9 & E9 & https://www.gov.uk/government/speeches/pm-statement-on-coronavirus-25-march-2020 \\
\hline
\end{tabular}

\section{APPENDIX B}

\section{LIST OF SPEECHES OF THE USA}

\begin{tabular}{lll}
\hline S no & Speeches & $\begin{array}{l}\text { https://www.washingtonpost.com/politics/2020/03/11/trump-coronavirus-addU1ress- } \\
\text { transcript/ }\end{array}$ \\
\hline 1 & U1 & $\begin{array}{l}\text { https://www.rev.com/blog/transcripts/donald-trump-speech-transcript-declares- } \\
\text { coronavirus-national-emergency }\end{array}$ \\
\hline 2 & U2 & $\begin{array}{l}\text { https://www.whitehouse.gov/briefings-statements/remarks-president-trump-vice-president- } \\
\text { pence-members-coronavirus-task-force-press-conference-3/ }\end{array}$ \\
\hline 3 & U3 & https://theconversation.com/donald-trumps-chinese-virus-the-politics-of-naming-136796 \\
\hline
\end{tabular}




\begin{tabular}{lll}
\hline 4 & U4 & $\begin{array}{l}\text { https://www.nbcnews.com/politics/donald-trump/photo-trump-remarks-shows-corona- } \\
\text { crossed-out-replaced-chinese-virus-n1164111 }\end{array}$ \\
\hline 5 & U5 & $\begin{array}{l}\text { https://www.whitehouse.gov/briefings-statements/remarks-president-trump-vice-president- } \\
\text { pence-members-coronavirus-task-force-press-briefing-3/ }\end{array}$ \\
\hline 6 & U6 & $\begin{array}{l}\text { https://www.whitehouse.gov/briefings-statements/remarks-president-trump-vice-president- } \\
\text { pence-briefing-nurses-covid-19-response/ }\end{array}$ \\
\hline 7 & U7 & $\begin{array}{l}\text { https://www.theguardian.com/us-news/2020/mar/22/trump-coronavirus-election-november- } \\
2020\end{array}$ \\
\hline 8 & U8 & $\begin{array}{l}\text { https://www.whitehouse.gov/briefings-statements/remarks-president-trump-vice-president- } \\
\text { pence-members-coronavirus-task-force-press-conference-4/ }\end{array}$ \\
\hline
\end{tabular}

